\title{
REALANALYSERNE - TO SKRIDT FREM OG ET TILBAGE?
}

Jens Brinch og Tyge Kjær

En af de væsentligste marxistiske teoridiskussioner indenfor de sidste år har været centreret omkring rea lanalyseproblemet. Diskussionen af dette problem, der herhjemme især tog fart med udgivelsen af Jens Brinchs analyse af efterkrigstidens danske kapitalakkumulation, har dog haft tendens til at indsnævres til en diskussion om tekniske problemer i forbindelse med inddragelse af empirisk materiale i den marxske teori og har som konsekvens heraf lidt af en manglende problematisering af realanalysens teoretiske grundlag og - hvad der er nok så vigtigt - af dens politiske formål.

I den følgende artikel tages begge disse problemer op i programatisk form $i$ håb om at sætte nye perspektiver for diskussionen, uden at der dermed intenderes endegyldige svar på problemerne.

Bæredygtigheden af de her diskuterede perspektiver kan bl.a. afprøves overfor de mest udviklede realanalyseforsøg. Som sådan kan artiklen også tjene som en problematisering af visse af de teoretiske ansatser, der ligger til grund for Altvater m.fl.'s analyse af akkumulationsudviklingen i BRD, som også bringes i dette nummer. 
I den danske marxrekonstruktions udvikling er man i dag nået ind i en omfattende brydningsfase, hvor brydningerne er mangesidede. Der er veludviklede sekteriske fraktionsbrydninger, brydninger mellem »kapitallogikere« og »klassekæmpere« samt brydninger inden for universitetsmarxismens forskellige teoretiske og politiske tendenser. Under sidstnævnte er realanalyseproblematikken efterhånden blevet særlig væsentlig, fordi den har fors $\emptyset$ gt at indplacere de empiriske, konkrete analyser $i$ en teoretisk formidlingssammenhæng. Samtidig er det også et beklageligt faktum, at realanalyseforestillingen i dag mange gange fungerer som en »marxistisk « legitimering af den skinbarlige empirisme.

Denne artikel, som er fremkaldt af Altvater m.fl.s empiriske analyse af akkumulationsudviklingen i Tyskland vil derfor forme sig som dels en skitsemæssig angivelse af den reflektionsramme, som det empiriskes problem har været stillet (og løst) i, og dels en abstrakt kritik af de implicitte forudsætninger, som Altvater m.fl.s analysemåde arbejder ud fra.

\section{2.}

Problematiseringen af empiriens status og betydning foregik i studenteroprørets første fase. Det danske studenteroprør, som udgik fra de samfundsvidenskabelige fag i bred forstand (sociologi, psykologi, planlægning mv.) i 1968-69, var ikke alene båret frem af det formelle krav om medbestemmelse og demokratisering af universiteterne; det omfattede også et indholdsmæssigt opgør med de etablerede videnskabsdiscipliner, formuleret som en kritik på et videnskabsteoretisk plan af den logiske positivisme og på et politisk plan af den postulerede værdifrihed i videnskaben. Videnskabskritikken var i denne fase metode- og ideologikritik, og den lå dermed helt og holdent inden for de rammer, som det borgerlige kritikbegreb sætter.

Metodekritikken eller positivismekritikken viste, at de etablerede videnskabsdiscipliner abstrakt set var selvmodsigende, fordi de forsynede sig mod deres egne videnskabelighedskriterier. Ideologikritikken viste, at de konkret betragtet var ligeså selvmodsigende, fordi værdifrihedsidealet ikke kunne opretholdes dvs. at videnskaberne ikke var klasseneutrale, men bærere af en reformistisk ideologi og praksis.

Hele denne fase er senere blevet omskrevet til betegnelsen »intern fagkritik«, hvormed man også har sagt, at den ikke bevægede sig ud over det borgerlige kritikbegreb. Kritikken havde i første omgang ingen overskridende momenter, men kunne snarere betragtes som en tilpasning af de borgerlige videnskaber til de eksisterende samfundsmæssige betingelser - en modernisering og en reformulering af deres selvmodsigende elementer, f.eks. i form af en metodeudvikling.

I løbet af den interne fagkritik blev de empiriske analysers indhold og anvendelighed problematiseret i en sådan grad, at man måtte forholde sig helt 
negatorisk til empirien. Positivismekritikken var dermed oprindelsen til 'det empiriske problem'.

Allerede i selve problematiseringsfasen fremkom der mange forskellige forslag til en løsning af empirismeproblemet. Sydfra kom hermeneutikken, fra Norge kom det, som senere blev den populistiske aktionsforskning, fra USA kom Marcuse og de radikale sociologers krav om »a partisan sociology«. Fælles for disse forslag er, at de baserer sig på et moralsk krav om en individuel stillingtagen uden hensyntagen til videnskabens objektive samfundsmæssige bestemmelser: når videnskaberne ikke var klasseneutrale, måtte dens udøvere vælge side i klassekampen. Den hyppigste demonstrationsparole i denne fase var »Forskning for folket, ikke for profitten«, og den var samtidig betegnende for retningen i det kritiske studenterarbejde. ${ }^{1}$

\section{3.}

Anden fase i studenteroprøret er ikke kronologisk afgrænset, men indholdsmæssigt. Her sker den begyndende udvikling mod det marxske kritikbegreb, som foregik spredt og springvis. Udviklingen forløb først som en metodologisk og videnskabsteoretisk afklaring, hvor den rene metodeforbedring kunne overskrides, derefter som et skift i problemfelt fra positivismekritik til 3. Verdens- og imperialismeproblematikken, og endelig som udviklingen af 'kapitallogikken'. Det er karakteristisk for størstedelen af den periode, at marxismen var et våben i den universitære kamp mod de etablerede videnskaber, idet den både udviklede en totalt forskellig videnskabsopfattelse og en række nye arbejdsfelter. Gennem rekonstruktionen af den marxske videnskabsopfattelse og det marxske kritikbegreb kunne de metodetekniske og ideologikritiske elementer i positivismekritikken overskrides. I sine forudsætninger og retning står det marxske kritikbegreb uden for det borgerlige samfund.

\section{4.}

I dag er den systematiske oparbejdelse og tilegnelse af den marxske forskningsog fremstillingsstruktur så veludviklet og udbredt, at den kapitalsystematiske forståelse er en reel faktor i den videnskabelige og (universitets)politiske udvikling. Kapitalsystematikkens udvikling er dog alt ialt foregået som en teoriintern proces under abstraktion fra kravet om en konkret formidling af den indhøstede viden.

1. Det ses tydeligt i KURASJE nr. 1 og 2 3, hvor sidstnævnte er udarbejdet i samarbejde med det daværende Institut for Proletarisk Videnskab: INPROV. 
Denne proces er nu ved at vende. Den esoteriske udvikling af kapitalsystematikken stilles stadigt hyppigere over for et formidlingskrav, som antager både politiske, metodiske og indholdsmæssige udtryk. I sammenhæng med realanalyseproblematikken er det især de forskellige løsninger på empirismeproblemet, som påkalder sig interesse.

Kravet om konkret formidling - dvs. kravet om, at de almene kapitalkategorier, som omhandler gennemsnitsbevægelser under gennemsnitsbetingelser, anvendes til en systematisering af det borgerlige samfunds mangeartede og tilsyneladende selvstændiggjorte overfladebevægelser - har ført til en udvikling af forskellige positioner, som kan opdeles i tre hovedformer: (1) tilbagefald til den »rene empiri«, hvor de nye problemstillinger og kategorier, som oparbejdes som resultat af marxrekonstruktionen, forlades og erstattes af en tro på, at tingene er, som de umiddelbart ser ud. Dette er det samme som at sige, at al videnskab er overflødig, og at den ideologi, som går under betegnelsen borgerlig videnskab, blot skal have et socialistisk fortegn eller et arbejderstandpunktsfortegn. (2) Subjektiveringstendenser og (3) objektiveringstendenser, som begge er karakteriseret ved en fastholdelse af de almene kapitalkategorier, men med et forskelligt subjekt for teorien, hvilket vi kommer ind på senere.

Hos Ole Marquardt finder man et eksempel på, hvorledes et nyt temafelt fører til en problematisk genoptagelse af en særlig afart af empiriske analyser: spørgeskemaunders $\emptyset$ gelsen ${ }^{2}$. Der er her tale om et tilbagefald, som er så meget mere bemærkelsesværdigt i betragtning af, at Ole Marquardts intention og analyse iøvrigt falder ind under det, som vi har kaldt objektiveringstendenserne. Dermed vil man også kunne finde »renere « eksempler på det omtalte tilbagefald, men ikke med så stor udbredelse i den løbende diskussion. Ole Marquardts genoptagelse af spørgeskemateknikken er problematisk, fordi den helt glemmer indsigten fra fagkritikkens tidlige faser. Her skal vi blot diskutere et enkelt eksempel.

Man kan som altid ved spørgeskemaundersøgelser vise stort set hvad som helst. F.eks. anfører OM s. 24 ud fra et spørgsmål i en tysk, såkaldt 'socialistisk' industrisociologisk undersøgelse, at »Det er altså ikke krav om 'bedre livskvaliteter', medlemsindflydelse, eller endog en større andel af formuen i samfundet,

2. Ole Marquardt: Konjunkturforløb og klassebevidsthed, $i$ : Den jyske Historiker nr. I. Århus 1974, s. 22-25.

For at forebygge misforståelser vil vi her fremhæve, at vi ikke diskuterer Ole Marquardts bog som sådan, hverken hans metode eller teser iøvrigt. Vi har taget et enkelt aspekt ud og diskuterer det, fordi vi mener, at det kan bruges til at eksemplificere en tendens i dagens empirismeproblematik: Vi hefter os udelukkende ved det, som vi finder problematisk: den kritikblinde genoptagelse af en bestemt del af spørgeskemametoden. Man kan opfatte kritikken som generel på dette punkt, dvs. samtidig rettet mod hele det empirisk-metodiske grundlag for mange af de 'arbejds-' eller 'industrisociologiske' unders $\varnothing$ gelser (Kern \& Schumann, Popitz, Deppe m.fl.).

Hvis man sammenligner denne type unders $\varnothing$ gelser med f.eks. Marx' spørgeskema (Fragebogen für Arbeiter, MEW 19, s. 230-237), som hyppigt fremdrages som argument for, at man kan bruge spørgeskemaet fornuftigt, vil man opdage, at Marx ikke rammes af vores kritik, fordi han i eminent grad undgår ethvert forsøg på holdningsregistrering. 
der stilles til fagforeningerne, men i langt overvejende grad krav af eksklusiv materiel karakter.« Denne konklusion stammer fra svarfordelingen på et spørgsmål til strejkende og ikke-strejkende men informerede arbejdere om fagforeningernes vigtigste opgaver for tiden. Men hvis OM havde taget svarfordelingen på et af de andre spørgsmål, ville han være nødt til at modificere sin konklusion, fordi heraf fremgår, at prioriteringen af de mål, som fagforeningerne skal kæmpe stærkest for, også indeholder krav om »bedre livskvaliteter « - her defineret i forhold til spørgsmålet som nedsættelse af pensionsalder, mere retfærdig formuefordeling, bedre alderdomsforsorg, udvidet medbestemmelse m.v. ${ }^{3}$

Vi skal ikke fors $\emptyset$ ge at afveje disse modstridende svartendenser i forhold til hinanden, fordi pointen er, at man overhovedet ikke kan forvente at få anvendelige svar på de sk. holdningsspørgsmål af metodeimmanente grunde. Det andet spørgsmål, som OM citerer (s. 23) »Hvem repræsenterer efter Deres mening arbejdernes interesser bedst her i samfundet? « udtrykker intet som helst. Hvad ligger der f.eks. i »arbejdernes interesser «? Med de svaralternativer, som er givet på forhånd, er der tale om helt generaliserede interesser, hvor spørgsmålet kun udløser en bestemt svardisposition, men ikke nødvendigvis en handlingsdisposition hos den udspurgte. Han kan vælge mellem de forskellige politiske partier, staten, kirken og arbejdsgiveren, men kan ikke - eller kun hvis han misforstår spørgsmålet - få associationsbaner i retning af f.eks. strejkekomitéen. Spørgeskemateknikken forudsætter, at holdningen eller meningen er en ydre attribut ved individet, som aktualiseres i selve interviewsituationen, hvorefter den kan måles. De generaliserede interesser er ikke en eksisterende egenskab ved arbejderen, men derimod en egenskab, som tvangsmæssigt tillægges ham i selve interviewsituationen. Resultaterne er ikke alene uanvendelige som en følge af egenskabernes manglende attributkarakter, men også som en følge af den manglende endimensionalitet i spørgsmålet. Dækker»fagforeningen « f.eks. ledelsen i DGB eller LO og den aktive tillidsmand på samme tid? Med en mindre ændring i spørgsmålsformuleringen fremkalder og måler man helt andre attributter, og derfor kan man få de resultater, som er (politisk?) Ønskværdige. Som man råber i vinden, får man svar!

Denne indsigt førte i studenteroprørets tidligere faser til en omfattende negation af »empirien«, her forstået som den dengang fremherskende interviewbaserede dataindsamling inden for de samfundsvidenkabelige fag ${ }^{4}$. Og på denne baggrund er den metodeblinde genoptagelse af empirien, fremkaldt af kravet om konkretisering og realanalyse, ikke blot ét, men adskillige skridt tilbage. I Ole

3. Jfr. den samme rapport, som Marquardt citerer, SOFI: Am Beispiel der Septemberstreiks, Frankfurt 1971, s. 215-16.

4. At afvisningen ikke var total, kan man bl.a. se hos Vilhelm Borg: Industriarbejde og arbejderbevidsthed, Kbh. 1971. Hos VB finder man s. 13-15 en opsummering af nogle af interviewmetodens problemer uden at hans løsning, som er en skelnen mellem en »god « og en »dårlig « empiri, bliver mere acceptabel end Marquardts accept af de tyske socialistiske industrisociologers resultater. 
Marquardts tilfælde er referencerne til SOFI-unders $\emptyset$ gelsen endda helt overflødige, fordi han ud fra sit teoretiske udgangspunkt sådan set har bestemt det, som er hans egentlige ærinde: sammenhængen mellem fagforeninger og socialpartnerbevidsthed. ${ }^{5}$

\section{5.}

I en lidt mere generel betragtning er det tydeligt, at den danske marxismes udvikling i dag foregår i et felt mellem to modsat rettede tendenser: en subjektiverings- og en objektiveringstendens.

Subjektiveringstendensen er lettest at identificere. Den er især karakteristisk for de forskellige grupperinger inden for den organiserede venstrefløj. Med subjektiveringstendens menes, at kravet om en videreudvikling af den marxske kapitalismeanalyse ikke betragtes som en nødvendighed af samme karakter som det politisk mobiliserende arbejde, som netop derfor ofte hviler på et rent moralsk og ideologikritisk fundament uden egentlig indarbejdelse af teoriens afdækning af de objektive, strukturelle samfundsmæssige sammenhænge som modsætningen mellem kapital og lønarbejde konkret udvikles i. Teorien amputeres; marxismen-leninismen bliver reelt subjektløs og kun et varemærke.

De programmatiske krav, som den postuleret revolutionære organisation vil opfylde, er og bliver en alvorlig hemsko for en seriøs og omfattende kapitalismeanalyse samt for en strategi, der jo også må have en teoretisk reflektionsramme. Forskellene mellem de mange grupperinger på venstrefløjen er ikke af indholdsmæssig art, men i overvejende grad af polisitisktaktisk art. Det er et tydeligt udtryk for, at politikken gøres udvendig i forhold til teorien, og organisationerne må derfor agere ligeså udvendigt: de agerer alle på politikkens supermarked med konkurrence mellem og inden for organisationerne om enkeltarbejdernes gunst. Der tordnes mod konkurrentens »vare « - den korrekte politiske linje med beskyldninger for socialfascisme, revisionisme og andre angivelser af den absolut manglende kvalitet. Selv om arbejderklassen her angiveligt er subjekt for politikken og dens principielle teoretiske basis, er den teoretiske basis kun moralsk funderede udsagn uden egentlig indsigt i den strukturelle sammenhæng i kapitalismen, som politøkonomien er det begrebslige udtryk for. Karakteristisk har da også været først en almindelig teoriforskrækkelse, så en omfattende teorifjendtlighed, som kan ses inden for alle venstrefløjens grupper, i hvert fald fraktionsvis. ${ }^{6}$

5. Jfr. også Redaktionskollektiv Gewerkschaften i KURASJE 11, hvor sammenhængen udvikles i en mere omfattende kapitalsystematisk ramme.

6. KF har tilsyneladende været en hæderlig undtagelse, idet man i det mindste programmatisk har fastholdt kravet om at udvikle en egentlig kapitalismeanalyse under bibeholdelse af marxismens revolutionsteoretiske aspekt. Men selv KF præges af modsætninger mellem militant reformisme og seriøs kapitalismeanalyse. 
Inden for subjektiveringstendensen bliver det teoretiske arbejde enten opfattet som en blokering over for det vigtige - den politiske kamp, som meget hyppigt forkortes til at være en individuelt baseret, perspektivløs strejkekamp (Uniprint f.eks.), hvor man på trods af den åbenlyse sejr for 'kapitalens logik' (rationalisering og intensivering med deraf følgende fyringer) må udråbe selve kampen til en bevægelse i klassekampen og en styrkelse/højnelse af klassebevidstheden - eller gjort til en efterrationalisering af en i forvejen lagt strategi. Dette er særligt tydeligt for DKPs vedkommende, hvilket hele Stamokap-kritikken har vist.

Objektiveringstendensen er karakteristisk for universitetsmarxismen, hvor den findes $i$ to forskellige former: den ultravidenskabelige og den politiske.

Den ultravidenskabelige objektivering af marxismen, som samtidig er den rene pervertering, udtrykker sit fundamentale standpunkt i følgende klip: »Vores kritik af kapitallogikken er baseret på elementore videnskabelighedskriterier ... «7

Parallellen til alle de tidligere gange, hvor Marx' kapitalismeanalyse er blevet tilbagevist ved hjælp af helt elementære videnskabelighedskriterier er iøjnefaldende. I nutidens danske utralvidenskabelige objektiveringstendens ligger der samtidig en omfattende tendens til at anvende marxismen interdisciplinært, hvorved marxismens revolutionsteoretiske aspekter bliver bortamputeret og erstattet af Videnskabelighedsprotesen. Konsekvensen er, at marxismen bliver brugt til at udvikle en bedre $\varnothing$ konomi end den eksisterende national $\varnothing$ konomi, en bedre (arbejds)psykologi end den nuværende, en bedre planlægning end osv. Her har marxismen kun interesse som korrektionsfaktor i forhold til de eksisterende fagdiscipliners enkeltvidenskabelige begrænsninger, men er iøvrigt selv underlagt præcis de samme videnskabelighedskriterier - rekurrens, verifikation, gyldighed, pålidelighed osv. Politik og videnskab kan og skal ikke længere forekomme i en indre sammenhæng, dvs. formidlet over marxismen som revolutionsteori. Og som en naturlig følge bliver en af de første og vigtigste opgaver da også at efterprøve marxismen videnskabeligt, dvs. dels med hensyn til konsistens ('Marx var jo selvmodsigende'; 'Marx har aldrig udviklet en pristeori') og dels gennem en empirisk verifikation ('kapitalismen har jo forandret karakter til monopolkapitalisme, senkapitalisme' o.a.). Denne grundopfattelse er blevet betegnet »neoricardianisme « ud fra sin teoretiske forståelse, som er ét stort tilbageskridt i forhold til Marx, hvilket David Yaffe har vist i sin kritik Den kan også betragtes som en modernisering af Witt-Hansens Diamat-baserede Marxforståelse ${ }^{9}$.

Hvad skal den ultravidenskabelige objektivering af marxismen egentlig? Den fremstiller sig selv som politisk-revolutionær og mange af dens udøvere er organiserede personer. Man kan få svar på spørgsmålet ved at undersøge teoriens subjekt.

7. Interview med Carsten Koch, Christian Groth, Ole Jess Olsen og Heine Andersen $i$ : Studenterbladet (DSF) nr. 18, d. 22.5.75 s. 7. Vores fremhævelse.

8. D. Yaffe: Kritik af den neoricardianske marxisme, Århus 1975.

9. Witt-Hansen: Historisk materialisme, Kbh. 1973; jfr. også KURASJE 10, s. 106-7. 
Her er der nemlig kun ét muligt subjekt: den borgerlige stat, som indlysende nok hungrer efter en moderniseret og kompletteret økonomi, planlægning, sociologi, psykologi mv. til brug for sit krisemanagement. Dette behov bliver indlysende nok større i krisetider, hvor krisen muliggør en erkendelse af kapitalismen som det, den virkelig er: tilegnelse af andres merarbejde. I stedet for at udvikle dette perspektiv, ser repræsentanterne for denne opfattelse krisens årsag i en mangelfuld planlægning dvs. en forkert politik fra statens side ${ }^{10}$ eller i umådeholdne $l_{\emptyset n k r a v}{ }^{11}$. Denne objektivering af marxismen vil utvivlsomt være - eller kunne blive - det teoretiske grundlag for den statskapitalisme, ${ }^{12}$ som er en reel udviklingsmulighed for kapitalismen i dens nuværende fase. Statskapitalismens teoretiske grundlag må jo netop formuleres mere omfattende end den keynesianske og keynesinspirerede teori, som har været det nuværende socialdemokratis ramme for en forståelse af de samfundsmæssige bevægelseslove og deres dynamik. Neoricardianismen er objektivt en forbedring af denne forståelsesramme, men den holder sig på samme måde helt og aldeles inden for de rammer, som eksistensen af kapitalistiske produktionsforhold sætter, dvs. den er en forbedring under abstraktion fra kritikelementet i marxismen.

Den anden tendens i universitetsmarxismen blev tidligere kaldt den politiske, her ikke i organisatorisk forstand, men i indholdsmæssig. Dette betyder, at teoriens subjekt er den revolutionære arbejderklasse, og at denne teoriform er helt uden praktisk betydning i de faser af kapitalismens udvikling hvor den revolutionære arbejderklasse ikke manifesterer sig som sådan, men som en reformistisk arbejderbevægelse. Den politiske universitetsmarxisme skal - som Mattick har formuleret det - fastholde marxismen som en indholdsmæssig revolutionsteori (altså den ortodokse marxforståelse, om man vil) fra cyklisk nedgang over opgang til den næste nedgang, således at der altid findes en formuleret teoretisk forståelse af det kapitalistiske samfunds udviklingsdynamik i alle dens facetter. Det er f.eks. væsentligt at fastholde en forståelse af kapitalismens nødvendigvis krisefyldte udviklingsmåde under opgang og højkonjunktur, hvor denne udviklingsmåde ikke eksisterer realt som sådan. Den reale udvikling synes faktisk at vise det stik

10. Jfr. Bengt Åke Lundvall i Information d. 11., 13. og 14. marts 1975. hvor krisens årsag entydigt føres tilbage til en bevidst forfejlet boligpolitik. Eller det interview, som omtales i note 8 .

11. Jfr. Chr. Groth $i$ : Kapitalakkumulation i Danmark II - diskussion og kritik, Kbh. 1975.

12. Med statskapitalisme mener vi her hverken monopolkapitalisme, statsmonopolkapitalisme eller andre afgrænsninger af en fasespecifik kapitalismeform, som indeholder en ofte implicit antagelse om, at kapitalismen har forandret karakter, dvs. at dens bevægelseslove er blevet forandret. Det eneste, som har forandret sig, er distributionsformerne, og statskapitalisme indebærer dermed blot, at staten er - dvs. har udviklet sig til at være - permanent eksekutor af kapitalens iboende lovmæssigheder. Efterhånden som statskapitalismen udvikler sig ud over den nuværende blandings $\varnothing$ konomi, vil eksekutorfunktionen blive et helt integralt moment i bevægelseslovenes gennemslagsform. Det er ensbetydende med, at vi opfatter staten som et moment i gennemsnitsprofitratens dannelse og at dette moment allerede er af central betydning på nationalstatsligt plan i dag. 
modsatte, hvilket ses tydeligt af udviklingen i 1960'erne, især første halvdel. Her modsiger den reale, materielle udvikling næsten totalt den teoretiske krisecyklus. Ser man udviklingen i lidt større perioder; er det en afgørende mangel, at der i dag ikke findes overleverede erfaringer fra krisen i 1930'erne. Fagforeninger, arbejderbevægelse, venstrefløjsgrupper og universitetsmarxister står uden egentlig historisk formidlet erfaringsgrundlag i krisesituationen. Ud fra denne mangel kan den politiske universitetsmarxismes opgave afgrænses: den skal så at sige være en kuvøse, der holder liv i en revolutionær teori i perioder, hvor den er uden materiel forankring.

Dette sætter bestemte indfaldsvinkler i centrum for den teoretiske kapitalismeanalyse, hvilket behandles senere, og kan samtidig begrunde empiriske analyser. De empiriske analyser skal dog ikke gennemføres ud fra snævert videnskabelige grunde, men ud fra politiske, hvilket selvfølgelig også rummer en del problemer. Et af problemerne er, at de empiriske analyser som »realanalyse« tit og ofte bliver betragtet som en løsning på universitetsmarxismens såkaldte isoleringsproblem, hvor realanalysen antages at kunne skabe forbindelsen mellem universitetsmarxismen og de progressive dele af arbejderbevægelsen. Man kan som Altvater fremhæve, at den empiriske analyse er nødvendig for at udvikle klassekampens mulighedsbetingelser i alle akkumulationsprocessers cykliske faser, herunder også under boom'et. De specifikke historiske analysers nødvendighed i deres empiriske form begrundes politisk, idet de skal medvirke til at gennembryde den hermetisk lukkede, cirkulære overfladeform, som har karakteriseret den stort set krisefri efterkrigskapitalisme. Det egentlige problem er her, at realanalysen nødvendigvis må knytte an til den almindelige bevidsthed, som arbejderne har som revenukildebesiddere, dvs. beskrive kapitalismens udvikling konkret og empirisk på overfladens betingelser, altså under anvendelse af gængse nationaløkonomiske opgørelser, samtidig med at den eneste mulige forklaring på disse overfladebevægelser skal være den marxske akkumulations- og kriseteori.

I artiklen af Altvater, Hoffmann, Schöller og Semmler udvikles den almene sammenhæng mellem dybde og overflade for at udarbejde sammenhængen mellem »beskrivelsesniveauet « og »forklaringsniveauet « - altså for overhovedet at gøre den traditionelle nationaløkonomi tilgængelig for en marxsk, kapitalsystematisk forklaring. På denne basis udvikles forskellige elementer til en empirisk analyse af akkumulationsprocessen ud fra profitratens bevægelser i dennes overfladeformer - med henvisning til, at selv Marx fors øgte sig med talmæssige opg $\varnothing$ relser af akkumulationsprocessens cykliske »ups and downs«.

Hvor Marx opgav, gennemfører Berlinerfolkene deres analyse, og de spørgsmål, man derfor må stille til deres analyseform, er for det første om den teoretiske formidling mellem dybde og overflade, mellem nationaløkonomi og kapitalsystematik er gennemargumenteret, og for det andet om den politiske formidling lykkes. Formidlingen mellem overflade og dybde er ikke kun et »teknisk « eller metodisk problem, selv om det ofte fremstilles sådan. Det er vigtigt at huske hensigten bag denne formidlingsproblematik, som indholdsmæssigt er at vise, 
at visse, blot kvantitative forandringer - som altid kan vises empirisk - kun kan forstås og begribes ud fra grundliggende, kvalitative forandringer. Kravet til den empiriske analyse bliver således på den ene side at vise, at empirisk konstaterede forandringer, f.eks. i vækstraten, qua nødvendige overfladeformer kun er mulige, fordi akkumulationsprocessens betingelser, dvs. valoriseringsgraden, har forandret sig. På den anden side skal denne empirisk og teoretisk formidlede indsigt også kunne styrke en socialistisk politisk udvikling, som ikke blot baseres på et arbejderstandpunkt.

\section{6.}

Enhver empirisk analyse står umiddelbart i fare for at falde tilbage i en borgerlig symptomatologi, dvs. overfladiske og overfladebundne observationer, der ikke reflekterer kapitalismens indre bevægelseslove. Garantien for, at den empiriske analyse - opfattet som realanalyse - undgår denne fare, er hos Berlinerfolkene, at alt empirisk materiale kun anvendes som illustration af de fundamentale kategorier og deres udviklingsdynamik, hvorimod det kan anvendes som en fremstilling af overfladekategorierne selv. Man foretager her en skelnen mellem overfladekategorier og disses selvstændige dynamik og væsenskategorier, der ikke fremtræder som sådanne, men i overfladens kategorier og bevægelser ${ }^{13}$.

Når de empiriske oplysninger, der udtrykker og fremstiller overfladebevægelserne, skal kunne illustrere de dybdebevægelser, som ikke har nogen selvstændig empirisk form i sig - dvs. at de skal fungere som indikatorer for værdibevægelsens retning - må man nødvendigvis arbejde ud fra en antagelse om, at der er et parallelt retningsforl $\phi b$ eller parallelle tendensbevægelser i hhv. pris- og værdibevægelse. Dette skyldes jo, at »I konkurrencen fremtraeder derfor alt i fordrejet form. De økonomiske forholds færdige skikkelse, således som den viser sig på overfladen, i sin reale eksistens, og dermed også i de forestillinger, med hvilke disse forholds bærere og agenter søger at forstå disse forhold, er meget forskellig fra deres indre, væsentlige, men tilslørede kerneskikkelse og i virkeligheden en fordrejelse af, en modsætning til denne kerneskikkelse og det dertil svarende begreb. « ${ }^{14}$ Denne fordrejelse får naturligvis konsekvenser for produktionsmådens agenter: »Således lever den kapitalistiske produktions agenter i en fortryllet verden, og deres egne relationer fremstår for dem som tingenes egenskaber, egenskaber ved produktionens stoflige elementer. Kapitalens skikkelser fremtræder dog som produktionens virkelige agenter og umiddelbare bærer i disse sidste, mest formidlede former - $\mathrm{i}$ former, hvor formidlingen ikke alene er blevet uigenkende-

13. Jfr. s. 38 i dette nummer og s. 57 i Probleme des Klassenkampfs nr. 16, som bringes i Kurasje nr. 13.

14. MEW 25, s. 219/da. 3:2, s. 270. 
lig, men tydelig i sin direkte modsætning. $^{15} \mathrm{I}$ denne fortryllede verden, hvor alt forvandles til sin direkte modsætning, bliver den samfundsmæssige udviklings determinanter også forvandlet; lovene for den samfundsmæssige udvikling kan kun begribes gennem en teoretisk analyse, fordi empiriens verden er behersket af tilfældigheder: »...konkurrencens sfære, der beherskes af tilfældigheder, hvis man betragter det enkelte tilfælde; hvor den indre lov, der slår igennem i disse tilfældigheder og regulerer dem, således kun bliver synlig, når man sammenfatter disse tilfældigheder i store mængder, hvor loven således er og forbliver usynlig og ubegribelig for den enkelte produktionsagent selv. $\ll^{16}$

Man kan ganske vist hævde, at denne sammenfatning i store mængder, som muliggør en erkendelse af loven, også skal foretages empirisk - her endda statistisk-empirisk - men det er ikke en udtømmende sammenfatning, fordi den også indeholder elementer og momenter fra de formdannelser, som selve overfladeformen sætter. Også dette forhold gør Marx opmærksom på: »... den virkelige produktionsproces, som er en enhed af umiddelbar produktionsproces og cirkulationsproces, frembringer nye formdannelser, hvori den indre sammenhængs røde tråd mere og mere bliver borte, produktionsforholdene gør sig selvstændige over for hinanden, og værdibestanddelene stivner i selvstændige former over for hinanden. $\ll^{17}$

Analysens udgangspunkt må derfor nødvendigvis være overfladens kategorier og bevægelser, og hvis man skal kunne nå længere end den blotte registrering af overfladebevægelser, må den samme nødvendighed udstrækkes til at omfatte en antagelse om, at overfladebevægelser og væsensbevægelser, pris- og værdibevægelser forløber i samme retning, dvs. parallelt.

Allerede i formuleringen af parallelitetsantagelsen kan man se to forstyrrelser i parallelforløbet. Den første er den »relative inflation «, muliggjort af selve pris- og pengeformens eksistens, som betyder, at »markedspriserne i deres absolutte bevægelse nu ikke længere reflekterer værdibevægelsen, fordi den enkelte vares værdifald på grund af inflatoriske processer ikke længere giver udslag i prisfald. $\aleph^{18}$ Den anden forstyrrelse er eksistensen af ekstraprofitter, forårsaget af enten en arbejdsintensitet over gennemsnittet eller anvendelse af arbejdere med en overgennemsnitlig dygtighed. Denne forskydning udtrykkes i forskellen mellem markedspris og markedsværdi. Jo mere stabil muligheden for at opnå en ekstraprofit er, desto større vil afvigelsen mellem markedspris og -værdi være.

Ekstraprofitafvigelsen peger på endnu et spørgsmål, nemlig om hvor længe afvigelsen mellem pris og værdi kan forekomme. Og svaret må være, at prisen kan ligge over værdien lige så længe som krisecyklen varer. Krisens funktion i

15. MEW 26.3., s. 503-4.

16. MEW 25, s. $836 /$ da. $3: 4$, s. 1066

17. ibid.

18. jfr. s. 34 . 
kapitalakkumulationen er jo netop at skabe en ny enhed af alle de modsigelsesfulde momenter, som har selvstændiggjort sig mellem kriserne - dvs. også skabe en ny pris-værdienhed. Denne nye enhed er samtidig skabelsen af et nyt samfundsmæssigt gennemsnit for den værdiskabende arbejdstids omfang, hvilket indebærer, at muligheden for at opnå ekstraprofit i det store og hele forsvinder i krisen; men allerede under krisen genskabes muligheden for ekstraprofitopnåelse, men blot på basis af det nye gennemsnitsmål for den værdiskabende arbejdstids omfang under hensyntagen til den nye teknologi. Under krisen vil værdi og pris følgelig være sammenfaldende, mens de kan og vil afvige mellem kriserne, hovedsagelig i den retning, at værdien ligger lavere end prisen for alle varer $\mathrm{i}$ opgang og højkonjunktur, for at falde og nærme sig værdien under nedgang og depression. I selve krisen vil prisen falde under værdien på varer fra de kapitaler, som bukker under, da dette netop er »værdiforringelsesmekanismen «, men iøvrigt være tendentielt ens.

Forkortningen hos Berlinerfolkene består således i, at de på den ene side formulerer deres parallelitetsantagelse om samme retning i værdi- og prisbevægelse, samtidig med, at de på den anden side angiver nogle vidtrækkende modifikationer (relativ inflation, ekstraprofit) uden at medtænke disse. Hvis man gør det, viser det sig, at man ikke kan tale om en paralleludvikling i perioden mellem kriserne, men kun direkte under og lige omkring selve krisen.

Hvad betyder denne forkortning? Den betyder mindre for selve den metodiske grundantagelse om parallelitet end for empiriens anvendelsesområde. For det første skal man huske, at selv om prisen afviger fra værdien i et cyklisk udviklingsforløb, kan dette kun gælde i begrænset omfang, fordi prisen kan ikke alment afvige fra værdien, dvs. det kan ikke gælde for den samfundsmæssige totalproduktion som sådan. For den samfundsmæssige totalproduktion betyder voksende priser blot at den samme arbejdsmængde udtrykker sig i flere pengeenheder. Det kan derimod gælde branche- og sektorvis, samt for enkeltkapitalerne. For det andet vil afvigelserne altid udlignes i og under krisen. Derfor kan empiriens gyldighedsfelt inden for denne metodiske ramme ikke udstrakkes til at omfatte enkeltkapitaler, knap nok brancher, og ikke omfatte detailforlob inden for krisecyklen, hvor afvigelserne kan være så omfattende, at prisbevægelsen ikke indikerer værdibevægelsens udviklingsretning.

Hvis man ser på bestemmelsen af værdi og pris på arbejdskraften hos Berlinerfolkene, føjes en ny dimension til parallelitetsproblemet. For arbejdskraften gælder nemlig, at en prisstigning for arbejdskraften følges op af en værdistigning, hvis den højere pris fører til en forøgelse af konsumtionsniveauet, som kan fastholdes over en længere periode. Dette nye, højere konsumtions- eller reproduktionsniveau bliver det gennemsnit, hvorom prisen på varen arbejdskraft svinger ${ }^{19}$. Den mekanisme, som skitseres, forløber tilsyneladende således: f $\phi r s t$ vokser prisen på varen arbejdskraft som et udtryk for nye behov (og krav), hvil- 
ket er det samme som det moralske og historiske element i bestemmelsen af arbejdskraftens værdi, derefter sker der en tilsvarende forøgelse af arbejdskraftens værdi. Forudsætningen er naturligvis, at væksten i »levestandarden « er større end produktivitetsforøgelsen for de varer, som udgør reproduktionen, kvantitativt og kvalitativt.

Hermed har vi set to forskellige udformninger af parallelitetsforløbet. For den særlige vare arbejdskraft, hvor pris- og værdisættelse ikke udelukkende følger produktionens og markedets betingelser, men også klasseforholdet mellem kapital og lønarbejde, er der tale om en utvetydig parallelitet. Vokser prisen, vokser værdien tilsvarende, hvis det da ikke er et blot kortvarigt fænomen. Falder prisen, falder værdien, undtagen i de kortvarige fluktuationer, hvor kapitalisten jo altid forsøger at holde prisen på arbejdskraften under dens værdi, især i krisesituationer. Hvis arbejderklassens defensive kamp mod kapitalens despoti lykkes, er resultatet, at prisen holdes omkring værdien. ${ }^{20}$ For alle andre varer gælder den modificerede paralellitet, som er anført ovenfor.

Selv om Berlinerfolkene utvivlsomt formulerer det systematisk korrekte udgangspunkt for forståelsen af forholdet mellem kapitalsystematik og konkrete historiske udviklingstendenser i deres metodiske værdiprisformidling, er det en åbenlys mangel, at de modificerende momenter ikke indreflekteres, men blot opregnes. Det egentlige spørgsmål må derfor nu blive, om den anførte modsigelse i antagelsen om paralleludvikling i prisog værdibevægelse kan løses i en ny bevægelsesform og i givet fald hvilken? Vores tese er her, at man i Marx' markedsproduktionsprisbegreb kan finde ansatser, der gør en systematisk løsning af parallelitetsproblemet mulig.

Hos Marx er markedsproduktionsprisbegrebet ikke udviklet overhovedet, men blot omtalt i to passager. Der er således ikke tale om færdige bestemmelser, men om en rekonstruktion, som i hvert fald delvis hører hjemme i 'bogen om konkurrencen', altså den systematiske udvikling og konkretisering af konkurrencebegrebet og konkurrencens historiske former. Denne opgave falder helt uden for denne artikels rammer, og vi skal derfor kun angive enkelte principielle og summariske argumentationslinjer.

Markedsproduktionsprisbegrebet er tilsyneladende den yderste formidlingskategori hos Marx i den forstand, at det er værdiens mest modificerede udtryk, modificeret af kapitalernes konkurrence. Konkurrencens modifikationer er selv dobbelt bestemt ud fra dens to former, dels som konkurrence inden for en produktionsgren og dels som konkurrence mellem forskellige produktionsgrene. Konkurrencen inden for branchen er en konkurrence på varemarkedet, altså om vareafsætningen (f.eks. priskonkurrence mellem varer med samme brugsværdi), mens konkurrencen mellem brancherne er en konkurrence om det mest profitable kapitaludlæg (f.eks. investeringskonkurrence om ekstraprofit, der kan foregå i form af aktiekøb).

20. Dette er et af de væsentlige elementer, som indgår i bestemmelsen af fagforeningerne; jfr. Kurasje 11, s. 30. 
Konkurrencen inden for en branche skaber værdiens første forvandlede form: markedsvardien. - I denne forbindelse skal man huske, at varens værdi er bestemt af den samfundsmæssigt nødvendige arbejdstid, som er medgået til dens produktion, hvor den samfundsmæssigt nødvendige arbejdstid selv omfattes af to bestemmelser: dels som den gennemsnitlige samfundsmæssige arbejdstid, der anvendes inden for branchen af gennemsnitlig intensitet og dygtighed, og dels som en proportional del af den samfundsmæssige totalarbejdstid, dvs. branchens andel af denne.

»For at varer fra den samme produktionssfære af samme art og tilnærmelsesvis samme kvalitet bliver solgt til deres værdi, kræves to ting: For det første må de forskellige individuelle værdier være udlignet til én enkelt samfundsmæssig værdi, den tidligere omtalte markedsværdi, og hertil kræves der konkurrence blandt producenterne af den samme slags varer, ligesom der kræves, at der findes et marked, hvor de alle udbyder deres varer til salg. $\ll^{21}$

For det andet må den producerede varemængde svare til det samfundsmæssige behov: »For at en vare bliver solgt til sin markedsværdi, dvs. i forhold til det samfundsmæssigt nødvendige arbejde, der rummes i den, må det totalkvantum af samfundsmæssigt arbejde, som anvendes på totalmassen af denne vareart, svare til det kvantum af samfundsmæssigt behov, der findes for den, dvs. til det betalingsdygtige samfundsmæssige behov. $\ll^{22}$

Hvis den anvendte arbejdstid til produktionen af en vare er gennemsnitlig for branchen, og hvis branchens samlede forholdsmæssige andel af den samfundsmæssige totalarbejdstid svarer til behovet, kan vareværdien dermed fremstå som markedsværdi. Det er i første omgang formbestemmelsen af værdiens markedsform. Hvad så med dens størrelse?

Markedsværdien er hverken individuelt medgået arbejdstid - hvis det var tilfældet, ville dovne og udygtige arbejdskræfter med forældede maskiner jo først forbruge mere arbejdstid og derefter skabe større værdi - eller et simpelt, aritmetrisk gennemsnit inden for branchen. Markedsværdien for en bestemt vareart bestemmes derimod af den medgåede arbejdstid hos de producenter, der producerer den overvejende del af den pågældende varetype, uanset om der anvendes lidt eller meget arbejdstid, altså nærmest et typetal.

De kapitaler inden for branchen, som anvender mindre arbejdstid end den branchemæssigt gennemsnitlige, producerer mere værdi pr. tidsenhed. Varens individuelle værdi pr. styk vil således være under dens samfundsmæssige værdi, markedsværdien, og det anvendte arbejde har dermed skabt en ekstramerværdi eller en ekstraprofit. Det omvendte gælder for de kapitaler, der anvender mere abejdstid til vareproduktionen end den gennemsnitligt nødvendige. Når deres varer kommer på markedet, tæller de hver især kun som et eksemplar af deres art, dvs. at deres værdi (markedsværdi) er den arbejdstid, som er gennemsnitligt nødvendig. I realiseringen

21. Das Kapital, MEW 25, s. 190 da. 3:1, s. 233.

22. ibid. s. 202, da. 3:1, s. 249. 
viser det sig så - eftersom markedsprisen i dette tilfælde vil ligge under deres varers individuelle værdi - at de har anvendt for meget arbejdstid eller arbejdstid, der ikke var værdiskabende, selv om det var brugsværdiskabende, i og med, at det ikke svarer til det samfundsmæssige behov.

Dannelsen af markedsværdien i konkurrencen mellem kapitalerne inden for hver enkelt branche om afsætning af deres varer fører samtidig til en udligning af enkeltkapitalernes forskellige profitrater til en branchemæssig gennemsnitsprofitrate. Dermed består markedsværdien af kostprisen plus branchemæssig gennemsnitsprofit.

$\mathrm{Nu}$ er det ikke bare enkeltkapitalernes organiske kapitalsammensætning, der er forskellig, før den branchemæssige udligning. De forskellige branchers gennemsnitlige organiske kapitalsammensætning vil også være forskellig, bl.a. som følge af vidt forskellige materielle produktionsbetingelser, hvorfor branchernes profitrater også vil være forskellige. Brancher med en høj organisk sammensætning vil producere mere værdi på kortere tid og derfor opnå en ekstramerværdi eller -profit. Under forudsætning af kapitalbevægelighed som værdi (dvs. i første omgang som penge, f.eks. i form af kredit), ikke nødvendigvis som stof (fixkapital), vil kampen om ekstraprofit efterhånden medføre, at de branchemæssigt forskellige profitrater udlignes til en almen eller gennemsnitlig profitrate for alle $\varnothing$ konomiens brancher: »Denne gennemsnitsprofitrate er imidlertid ikke andet end den i procent beregnede profit i disse sfærer med middelsammensætning, hvor profitten derfor falder sammen med merværdien. Profitraten er altså den samme inden for alle produktionssfærer, idet den nemlig er udlignet på niveau med profitten i disse gennemsnitssfærer, hvor kapitalens gennemsnitssammensætning hersker. $\ll^{23}$

Denne udligning er et resultat af konkurrencens anden form: konkurrencen som følge af, at varerne er produkter af kapital, konkurrencen mellem brancherne om det mest profitable kapitaludlæg. Kapitalerne bevæger sig over i den branche, der pt. har den højeste profitrate eller hvor ekstraprofitmulighederne ser særligt lovende ud. Herved udvides produktionen af den pågældende vareart, og på et vist tidspunkt vil produktionen have fået et omfang, der overstiger det samfundsmæssige behov. Dermed må varekonkurrencen skærpes, markedsværdien og profitraten falde, især fordi der på dette tidspunkt er udlagt for meget kapital i denne branche. Efter en krise (strukturkrise), evt. kun en beskeden, vil processen gentage sig, og tendensen i disse bevægelser er dannelsen af en almen, gennemsnitlig profitrate samt værdiens forvandling til produktionspris: »De priser, der opstår ved at der dannes et gennemsnit af de forskellige profitrater inden for de forskellige produktionssfærer, og som lægges til kostpriserne i de forskellige produktionssfærer, er produktionspriserne. $\ll^{24}$

Gennemsnitsprofitrate og produktionspris er aldrig fikserede størrelser, men tendenser, som sætter sig igennem under konkurrencen om ekstraprofit 
og vareafsætning. Det er tendenser, som sætter sig renere og renere igennem med kapitalens fulde udvikling, her især med kreditvæsenets udvikling, som effektivt mindsker bindingerne på kapitalens bevægelighed mellem brancherne, og som for en tid endda kan »ophæve« den manglende bevægelighed som fixkapital.

De to typer af konkurrence glider altid over i hinanden og påvirker hinanden. Det gennemsnitlige prisniveau inden for en branche er således ikke alene bestemt af den brancheinterne konkurrence, men også af konkurrencen mellem brancherne. Det betyder, at der etableres to typer af gennemsnit: dels den gennemsnitlige kostpris og dels den gennemsnitlige profit. Summen af disse er netop den pris, hvormed varerne optræder på markedet - ikke markedsværdien, ikke produktionsprisen, men markedsproduktionsprisen; den yderste formidlingskategori, som omfatter konkurrencens dobbelte modifikation af værdiformen.

Markedsproduktionsprisen er dermed den systematiske kategori, hvori pris og værdi sammenføjes under hensyntagen til såvel produktions- og distributionsbetingelser, herunder også den relative inflation. Dvs. at markedsproduktionspriskategorien indeholder dobbeltbestemmelsen af det værdisættende arbejdes omfang: dels bestemt gennem den samfundsmæssigt gennemsnitlige arbejdstids omfang, dels gennem det købedygtige samfundsmæssige behov på markedet.

Under forudsætning af, at parallelitetsantagelsen lader sig udarbejde mere detaljeret, hvis markedsproduktionspriskategorien inddrages, er det både muligt og berettiget at betragte det statistisk sammenfattede udtryk kapitalrentabilitet som indikator for den begrebsligt og systematisk bestemte profitrates udvikling. Hvis en nærmere udarbejdelse giver som resultat, at parallelitetsantagelsen ikke kan fastholdes, vil kapitalrentabilitetens op- og nedgange ikke nødvendigvis skulle forklares som udtryk for profitratens bevægelse. Indtil videre må man dog gå ud fra, at Berlinerfolkenes udgangspunkt er systematisk korrekt, omend ikke udarbejdet fuldt ud..$^{25}$

Resultatet af disse overvejelser bliver altså, at prisbevægelserne i deres empiriskstatistiske former kan betragtes som indikatorer for de egentlige bevægelser, værdibevægelserne, men med dels cyklusbetingede modifikationer, dels omfangsmæssige begrænsninger. Indikatortanken indebærer desuden, at de empiriske udtryk som overfladeudtryk accepteres med deres »face value«, altså uden fors $\emptyset \mathrm{g}$ på at rense dem for den borgerlige statistiks vilkårlighed. Vilkårligheden, tilfældigheden og anarkiet er netop karakteristisk for overfladeformernes bevægelse og en del af deres egendynamik. Det er dog stadig et problem at bestemme, hvilken betydning, denne selvstændige overfladedynamik har som modifikation i værdiprisparalleliteten. For Berlinerfolkene betyder dette, at de udvikler en række indirekte mål, f.eks.

25. Denne principielle fastholden ved deres systematiske udgangspunkt indebærer ikke, at resten af udledningerne er acceptable. F.eks. er deres bestemmelse af vækstraten, som baseres på, at opsparing trods alt er lig investering, i sit fundament ikke forskellig fra Harrod-Domarfunktionen i den traditionelle national $\varnothing$ konomi, som overtages uden kommentarer overhovedet. Denne vækstrate har intet med kapitalsystematiske bestemmelser at gøre. 
for forholdet mellem produktivt og uproduktivt arbejde og merværdiratens bevægelse i denne sammenhæng. ${ }^{26}$ Dette skyldes, at kategorierne produktivt og uproduktivt arbejde aldrig kan optræde som overfladekategorier, hvorfor de aldrig kan afgrænses direkte empirisk. Berlinerfolkene afviser altså alle regressive bevægelser, fordi de tendentielt bevæger sig hen mod at udarbejde en form for »værdistatistik«, der netop ikke findes i og med at værdiens nødvendige overfladeform er prisen (markedspris, markedsproduktionspris).

\section{7.}

Kan der overhovedet foretages kvantitative og kvalitative afgrænsninger af empirien på nuværende tidspunkt? Hvilke aspekter må inddrages i en bestemmelse af empiriens nødvendighed og tilstrækkelighed? Tidligere fremhævede vi, at det ikke kunne ske ud fra en videnskabsintern afgrænsning, da den ophøjede kritikken af den politiske $\varnothing$ konomi til Videnskaben og empirien til empirisme, og videre at afgrænsingen derfor måtte foretages politisk. Her skal vi nu afslutningsvis skitsere en reflektionsramme for denne politiske afgrænsing.

Den indholdsmæssige side af afgrænsningen må bestemmes ud fra Marx’ kritikbegreb, hvor der hele tiden er tale om en dobbelt kritik - kritik af teorierne om den kapitalistiske produktionsmåde, som samtidig er en kritik af det kapitalistiske samfund selv. Endelig er kritikken af den politiske økonomi også en positiv fremstilling af proletariatets politiske $\varnothing$ konomi. Kritikken skal påvise den kapitalistiske produktionsmådes historiske og bornerte karakter, vise, hvordan og hvorfor den beror på tilegnelse af merarbejde og at denne tilegnelse derefter bliver et middel til fortsat og forøget udbytning. Den skal vise, at kapitalen ikke alene er en skranke for sig selv, men også er en skranke for den virkelige rigdom: »Hele rigdommens udvikling beror på skabelsen af disponibel tid (/) Den nation, der arbejder i 6 i stedet for 12 timer, er virkelig rig. Rigdom er ikke kommando over merarbejdstid ... men disponibel tid for ethvert individ og for hele samfundet ud over den tid, som bruges i den umiddelbare produktion. $\ll^{27}$ Under kapitalistiske produktionsforhold bliver den virkelige rigdom altid kapitalens rigdom, dvs. akkumulation og reproduktion af kapitalforholdet - men dermed også underlagt kapitalforholdets iboende skranker. Den politiske refleksionsramme må derfor programmatisk og indholdsmæssigt være forbundet med en stadig påvisning af kapitalismens skranker, og dermed en teorikritik fra et standpunkt, som ikke kun er et arbejderklassestandpunkt, men en standpunkt, der rækker ud over kapitalismens selv: et revolutionært standpunkt. Her er empirien utilstrækkelig, og i en vis udstrækning unødvendig, fordi den ikke kan anvendes til andet end eksemplificerende fremstillinger af tendenser, som allerede er udledt teoretisk. En parallel til denne betragtning findes i kapitlet om den engelske fabrikslovgivning i Kapitalens 1. bind, som mest af alt har status af historiske

26. i artiklens 2. del.

27. Grundrisse, s. 594 (cit. fra »The Source and the Remedy« (1821) 
eksemplificeringer, selv om Marx også gennem eksemplificeringen kan fremdrage nye aspekter, som derefter kan indgå i en fortsat teoretisk formidling.

De empiriske analyser kan dog også ses ud fra en ren hensigtsmæssighedsafgrænsing, hvor de kan være nødvendige i forbindelse med reformismekritikken, dvs. med påvisningen af kapitalismens skranker i en konkret historisk periode. Et væsentligt element i reformismen er socialpartnerbevidstheden, og den er helt og holdent fikseret til værdiens bevægelse i revenuform. Her fremtræder alt arbejde som betalt, alle spor af værdiens oprindelse er udslettet, og hvis de empiriske analyser kan medvirke til at gennembryde denne bevidsthedsform - hvis de har en større politisk gennemslagskraft fordi de formuleres i en økonomisk, empirisk form - er de både nødvendige og berettigede. Samtidig vil indikatorformen være fuldt tilstrækkelig, selv om man til dato aldrig har set eksempler på, at klassekampen er blevet drevet afgørende frem af mellemlagenes kapitalismeanalyser.

I denne sammenhæng, hvor de empiriske analyser i heldigste fald kan formidle en kollektiv erfaringsramme og en strukturel forståelsesform, er det et problem, at empiri altid - og også her - opfattes som statistik, altså i en snæver økonomisk form. Empirien må naturligvis også omfatte det felt, som ligger uden for teoriens umiddelbare $\varnothing$ konomiske form, men inden for den sammenhæng, som de kapitalistiske produktionsrelationer sætter. I teoriens $\varnothing$ konomiske form optræder menneskene objektiveret som karaktermasker, bærere og personifikationer af bestemte samfundsmæssige former, der er præget af bestemte historiske produktionsforhold. Uden for teoriens $\emptyset$ konomiske form, men inden for de kapitalistiske produktionsforhold - og dermed inden for det empiriskes begreb - ligger selve denne prægning, som overhovedet ikke har været behandlet i nærværende sammenhæng. 